\title{
Histomorphologic characterization of the hepatopancreas of freshwater prawn Macrobrachium rosenbergii (De Man, 1879)
}

\author{
[Caracterização histomorfológica do hepatopâncreas do camarão-de-água-doce \\ Macrobrachium rosenbergii (De Man, 1879)] \\ M.A.S. Silva ${ }^{1}$, M.E. Almeida Neto ${ }^{2}$, B.O. Ramiro ${ }^{2}$, I.T.F. Santos ${ }^{2}$, R.R. Guerra ${ }^{1^{*}}$ \\ ${ }^{1}$ Aluno de pós-graduação - Universidade Federal da Paraíba - Areia, PB \\ ${ }^{2}$ Universidade Federal da Paraíba - Bananeiras, PB
}

\begin{abstract}
This study aimed to describe the Macrobrachium rosenbergii hepatopancreas histomorphology. The hepatopancreas is constituted by a set of blind end tubules, divided into proximal, middle, and distal regions, with the epithelium formed by E, F, B, R, and M cells differently of other species. Measurements of the length and width of the tubules were $419.64 \pm 69.09 \mu \mathrm{m}$ and $117.42 \pm 16.99 \mu \mathrm{m}$, respectively. The percentage of each cell type per region was: proximal region $(40 \% \mathrm{~B}, 20 \% \mathrm{~F}, 6.7 \% \mathrm{M}, 33.3 \% \mathrm{R})$, middle region $(45.4 \% \mathrm{~B}, 18.2 \% \mathrm{~F}, 9.1 \% \mathrm{M}$, and $27.3 \% \mathrm{R})$ and distal region $(36.4 \% \mathrm{E}, 27.2 \% \mathrm{~B}, 18.2 \% \mathrm{~F}, 9.1 \% \mathrm{M}$, $9.1 \% \mathrm{R})$. Cell $\mathrm{B}$ that stores glycogen and lipids, is the most commonly found cell in proximal and middle regions. In the distal region, the $\mathrm{E}$, responsible for the mitosis, is the most prominent. $\mathrm{M}$, responsible by nutrient storage, is numerically constant among the portions differently in the Macrobrachium amazonicum. The study for the first time also suggests that in addition to digestive enzymes, the F cell produces protective mucus. The present study generated for the first time a morphometric profile of $M$. rosenbergii hepatopancreas, demonstrating differences from other species, and can be an important tool for new studies in nutrition, reproduction, and production with the species.
\end{abstract}

Keywords: digestive gland, digestive histology, digestive morphology, F cell, shrimp

\section{RESUMO}

O objetivo do presente estudo foi descrever a histomorfologia do hepatopâncreas do camarão-de-águadoce Macrobrachium rosenbergii. Observou-se que ele é constituído por um conjunto de túbulos de fundo cego, sendo cada túbulo dividido em regiões proximal, média e distal, com o epitélio formado por cinco tipos de células $(E, F, B, R, M)$, diferentemente de outras espécies. As medidas de comprimento e largura dos túbulos foram de 419,64 $\pm 69,09 \mu \mathrm{m}$ e 117,42 $\pm 16,99 \mu \mathrm{m}$, respectivamente. A porcentagem de cada tipo celular por região foi: região proximal $(40 \% \mathrm{~B}, 20 \% \mathrm{~F}, 6,7 \% \mathrm{M}, 33,3 \% \mathrm{R})$, região média $(45,4 \% \mathrm{~B}$, $18,2 \% \mathrm{~F}, 9,1 \% \mathrm{M}$ e $27,3 \% \mathrm{R})$ e região distal $(36,4 \% \mathrm{E}, 27,2 \% \mathrm{~B}, 18,2 \% \mathrm{~F}, 9,1 \% \mathrm{M}, 9,1 \% \mathrm{R})$. Assim, a $\mathrm{B}$, que armazena glicogênio e lipídeos, é a célula mais encontrada nas regiões proximal e média. Na região distal, a célula $E$, responsável pela mitose, é a mais encontrada. A célula $M$, responsável pelo acúmulo de nutrientes, tem um número constante de células nas porções do túbulo, diferentemente do Macrobrachium amazonicum. O estudo também sugere, pela primeira vez, que a célula $F$ produz, além de enzimas digestivas, um muco protetor para o túbulo hepatopancreático. O presente estudo foi o primeiro a gerar um perfil morfométrico do hepatopâncreas do M. rosenbergii e demonstrou diferenças em relação a outras espécies, bem como serviu de importante ferramenta para novos estudos que abranjam a produção, a nutrição e a reprodução para a espécie.

Palavras-chave: camarão, célula $F$, glândula digestiva, histologia do sistema digestório, morfologia do sistema digestório

Recebido em 12 de janeiro de 2018

Aceito em 6 de abril de 2018

*Autor para correspondência (corresponding author)

E-mail: rromaoguerra@gmail.com 


\section{INTRODUCTION}

Macrobrachium rosenbergii is a species originating from Malaysia that belongs to the order of the decapods (Valenti, 2001). The decapods are characterized by a digestive system formed by the anterior gut (esophagus and proventriculus), the midgut, with a tubular region associated with the midgut (hepatopancreas) gland, and the posterior gut, which includes the rectum and the anus. Thus, the hepatopancreas is the main organ of the digestive system of the decapods and represents from 2 to $6 \%$ of the total body weight of the animal (Nunes et al., 2014).

The hepatopancreas receives different denominations, such as: liver, pancreas, midgut glands, gastric gland, digestive gland, anterior cecum, digestive diverticula, digestive organ, and middle intestinal gland. In most crustaceans, this organ presents different levels of structural and functional complexity. Within the order of decapods, the hepatopancreas is particularly well developed and forms a complex network of ducts and tubules in the blind end which occupies most of the cephalo-thoracic cavity (Gibson and Barker, 1979). It is involved in different functions, such as: food digestion, absorption of nutrients, storage of digestion products, mainly in the form of glycogen, and removal of residual material in the form of feces. Therefore, in crustaceans, it is considered the most effective and efficient organ of the digestive system (Vicentini et al., 2009).

The first cytological studies performed on hepatopancreas of crustaceans were performed by Dorman (1928), who initially indicated the presence of two types of epithelial cells: liver cells containing fats, and pancreatic cells containing enzymes. Jacobs (1928) extended this classification to four types of cells: E (embryonic), responsible for mitotic division; $\mathrm{F}$ (fibrillar), responsible for extracellular digestion; $\mathrm{R}$ (reabsorption), which contain glycogen and reserve lipid droplets, and B (vesicular) containing digestive enzymes. Marques Junior (2006) described five types of cells in the epithelium of hepatopancreatic tubules of prawn of Macrobrachium amozonicum species: E (undifferentiated) cells, F (fibrillar) cells, B (vesicular) cells, R (reabsorption) cells, and $\mathrm{M}$ (basal) cells, which had the function of storing nutrients.
However, for $M$. rosenbergii species of prawn, there is still neither a description of the types of cells found in the hepatopancreas nor a morphometric profile. Therefore, the lack of specific information on the different types of cells found in the epithelial tissue of the hepatopancreas in this species has generated uncertainties, mainly in relation to the digestion and assimilation of nutrients by hepatopancreas. This creates a point of instability in the formulation of artificial diets that will meet the nutritional requirements of the $M$. rosenbergii (Barros and Valenti, 1997). This gap is so great that there is no specific feed for the species. In commercial breeding, a saltwater prawn feed is used, although these prawns have morphological and physiological differences (Barros and Valenti, 1997).

Aiming to generate knowledge about the internal biology of $M$. rosenbergii freshwater prawn, the objective of this study was to perform a histological description of hepatopancreas and their cell types and their morphometric profile, in order to serve as a scientific basis for new studies in the areas of behavioral activity, physiology, nutritional management and reproduction for the species.

\section{MATERIAL AND METHODS}

For this study, 10 specimens of Macrobrachium rosenbergii freshwater prawn were used, with an average weight of $10.98 \pm 0.44 \mathrm{~g}$. The animals were collected at the fattening nursery of the Carciniculture Laboratory of the Federal University of Paraíba (UFPB), at the Center for Social and Agricultural Human Sciences, Bananeiras, Paraíba, Brazil, located in the microregion called Brejo Paraibano, at $06^{\circ} 45$ '00 " S $35^{\circ} 37^{\prime} 58 \mathrm{~W}$, at an altitude of $526 \mathrm{~m}$, with a rainy tropical climate and dry summers, with average temperature of $28^{\circ} \mathrm{C}$ in summer and $20^{\circ} \mathrm{C}$ in winter. The entire experiment was performed according to the norms and approval of the Ethics Committee on the Use of Animals of the Federal University of Paraíba, certificate number 096/2015.

After the capture in the fattening nursery, the animals were euthanized by thermal shock for dissection and excision of the cephalo-thorax and collection of the hepatopancreas. The second stage of the study was carried out at the Laboratory of Histology of the Graduate 
Program in Animal Science, at the UFPB, Areia, Paraíba, Brazil. The hepatopancreas samples were fixed in a $10 \%$ formalin solution, and then submitted to standard histological processing. The paraffin blocks were cut on a rotary microtome to a thickness of $5 \mu \mathrm{m}$.

Later, histological staining was performed with hematoxylin-eosin for the morphological verification of hepatopancreas, and histochemical staining was performed with periodic acid Schiff (PAS) + alcian blue $\mathrm{pH} 2.5$ for cell differentiation of the organ.

For PAS + alcian blue $\mathrm{pH} 2.5$ stain, the slides were hydrated in decreasing concentrations of ethyl alcohol, 100, 95 and $70 \%$, for 5 minutes each, and then washed for 5 minutes in running water. Then they were stained with alcian blue $\mathrm{pH} 2.5$, during 30 minutes and washed in distilled water. Subsequently, they were bathed in periodic acid for 10 minutes and washed in running water for 5 minutes, then bathed in sulfurous water for 2 minutes. Then, they were placed in Schiff's reagent for 10 minutes in the dark; washed in sulfurous water for 2 minutes, then in running water for 3 minutes. These slides remained in hematoxylin for 2 minutes and were again washed in water for 3 minutes for the reaction. Then the slides were dehydrated in increasing concentrations of ethyl alcohol, 70, $90,100 \%$, for 5 minutes each. Then diaphonized in xylol and the slide was mounted with Entellan. For identification, the slides were scanned under an Olympus BX-60 microscope coupled with Zeiss Axio Cam camera with Motic Image Plus 2.0 digital imaging capture software.

Photomicrographs were compared to cellular descriptions of the hepatopancreas of other shrimp species, such as, Macrobrachium amazonicum (Vicentini et al., 2009); Macrobrachium amazonicum (Ribeiro et al., 2014) and Farfantepenaeus brasiliensis (Nunes et al., 2014).

Morphometric analysis was also performed by using the Motic Image Plus 2.0 Program to determine the length and width of the tubules; and to calculate the proportion of the cells therein. For this, 10 photomicrographs of each hepatopancreatic tubule were digitalized. The length was measured from the apex to the basal region and the width at the middle region of the tubule. To determine the proportion of cells, the tubules were divided into 3 regions: proximal (region closest to the blind end of the tubule), middle (medial region of the tubule) and distal (region more distal to the end of the tubule) and then the total number of cells (E, B, F, R and M) were quantified in each region and then converted into percentage.

\section{RESULTS}

From the histological description, it could be observed that the hepatopancreas of Macrobrachium rosenbergii is constituted by a set of blind end tubules that connect to the main digestive tube and are immersed in the hemolymph. The tubules are connected by a connective tissue made up of collagen fibers and are coated by a pseudo-stratified epithelium that rests on the basal membrane. Throughout the tubule it was possible to differentiate three regions (proximal, middle, and distal) with 5 cell types and different cellular proportions between the regions (Figure 1A).

By hematoxylin and eosin stain, which basically consists in staining of basophilic (nucleus) and acidophilic (cytoplasmic) portions of cells, it was possible to identify and differentiate the types of cells found in the epithelial tissue of the hepatopancreatic tubules. Consequently, cell characteristics were defined, such as: position of the cell along the hepatopancreatic tubules, location and position of nuclei, reaction of the cytoplasm and the shape of each cell type.

The cells were identified as: E, defined as embryonic cells, had cuboid to prismatic shape with a large nucleus that occupies most of the cytoplasmic volume which is basophilic (Figure $1 \mathrm{E})$. This type of cell extends to the lumen of the tubule, and presents microvilli in the apical portion. We observed that this cell is located mainly in the distal portion of the hepatopancreatic tubule and is absent in the proximal and middle regions (Table 1).

M cells, defined as basal cells had a triangular shape and remained in contact with the basal lamina, but their apex did not reach the lumen of the hepatopancreatic tubule, and did not have microvilli. The nucleus is rounded and has several nucleoli, and the cytoplasm also presents intense basophilia (Figure 1C). The $\mathrm{M}$ cells are evenly distributed in the three regions of the tubules (Table 1). 


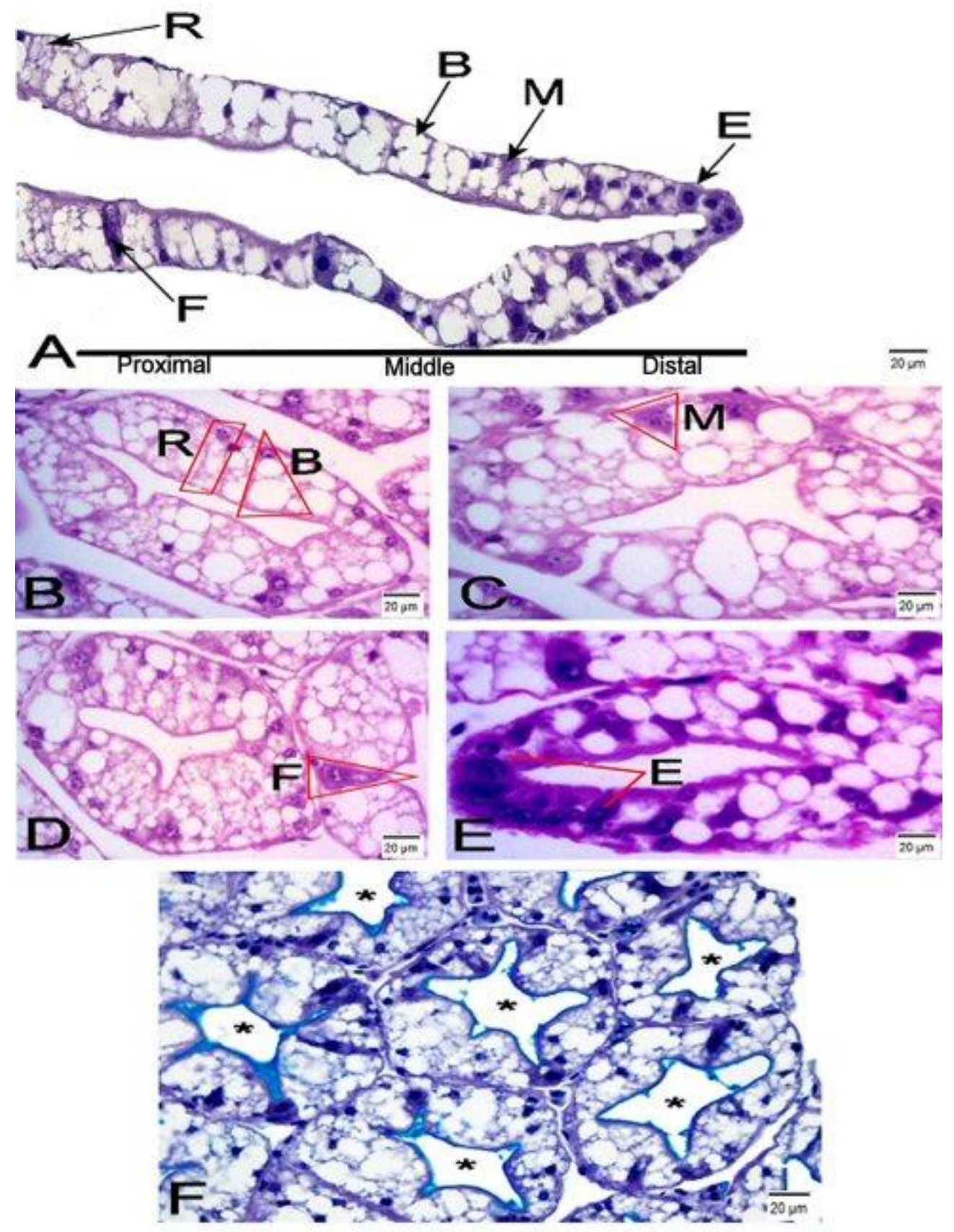

Figure 1. Photomicrographs of hepatopancreas in Macrobrachium rosenbergii freshwater prawn. A) Longitudinal section showing the hepatopancreatic tubule and the different cells (E, B, F, M, R) in the 3 regions of the tubule (proximal, medium and distal) with the periodic acid Schiff (PAS) + alcian blue staining technique. B) Transverse section of the tubule with hematoxylin-eosin staining, visualization of $\mathrm{B}$ cell with subapical vacuoles occupying most of the cytoplasm and basal nucleus and $\mathrm{R}$ cell with prismatic shape with acidophilic cytoplasm and basal nucleus. C) Identification of the $\mathrm{M}$ cell with the triangular shape, central nucleus and basophilic cytoplasm. D) Identification of the F cell presenting cytoplasm with intense basophilia with apical portion reaching as far as the lumen of the tubule. E) E cells with large nucleus occupying most of the cytoplasmic volume. F) Histochemical staining of PAS + alcian blue, highlighting the positive reaction to Alcian Blue for mucus (*) in the lumen of the tubule. 
Table 1. Distribution percentage of cell types in the proximal, middle, and distal regions of the hepatopancreatic tubules in Macrobrachium rosenbergii freshwater prawn collected from fattening nurseries

\begin{tabular}{cccc}
\hline & \multicolumn{3}{c}{ Regions of the hepatopancreatic tubules } \\
Cells & Proximal & Middle & Distal \\
\hline Cells E & - & - & $36.4 \%$ \\
Cells B & $40.0 \%$ & $45.4 \%$ & $27.2 \%$ \\
Cells F & $20.0 \%$ & $18.2 \%$ & $18.2 \%$ \\
Cells M & $6.7 \%$ & $9.1 \%$ & $9.1 \%$ \\
Cells R & $33.3 \%$ & $27.3 \%$ & $9.1 \%$ \\
\hline
\end{tabular}

F cells, defined as fibril cells, had a large and slightly elongated nucleus. The cells had a prismatic and / or triangular shape, and the cytoplasm also had intense basophilia. This cell type reaches the lumen of the tubule, and also had microvilli (Figure 1D).

B cells, defined as vesicular cells, had globular shape with a round basal nucleus. They were the largest of the cell types found. The cytoplasm presented several pinocytic apical vacuoles, always having one larger than the others, occupying much of the cytoplasm (Figure 1B). The B cell reached the lumen of the hepatopancreas tubule, the cytoplasm was acidophilic and there were microvilli in the apical portion of the cytoplasm.

$\mathrm{R}$ cells, defined as reabsorption cells, had a rounded nucleus located in the basal region, and its shape was generally prismatic, and had multivacuolar and granular cytoplasm. They are not basophils such as M, E and F cells, but they are neither acidophilic like B. They reach the lumen of the tubule and also have microvilli (Figure 1B).

Under staining with PAS plus alcian blue $\mathrm{pH} 2.5$ to identify lumen of the tubules of the hepatopancreas, which represents mucus (Figure $1 \mathrm{~F})$.

Morphometrically, the hepatopancreatic tubules of the $M$. rosenbergii had a length of $419.64 \pm 69.09 \mu \mathrm{m}$ and a width of $117.42 \pm 16.99 \mu \mathrm{m}$. From the identification of the three regions of the tubules, we can emphasize that $\mathrm{E}$ cells were found only in the distal region, making up $36 \%$ of the total cells in this region. B cells were the most frequent in the proximal and middle regions, and the second most common in the distal region of the tubules. The F cells were constant in the three portions of the tubules, between $18.2-20.0 \%$ of the total cell, as well as the $\mathrm{M}$ cell that had its proportion between 6.7$9.1 \%$ in the three tubular regions. $\mathrm{R}$ cells, however, had their proportions reduced towards the blind end of the tubule $(33.3,27.3$ and $9.1 \%)$ (Table 1).

\section{DISCUSSION}

In this study, the morphological characteristics observed in the hepatopancreas of Macrobrachium rosenbergii were similar to those found in Macrobrachium amazonicum with 5 cell types (Marques Junior, 2006; Ribeiro et al., 2014). However, these results differed from those found for Astacus Astacus (Vogt et al., 1989), Palaemonestes agentinus (Sousa and Petriella, 2000) and Litopenaeus vannamei (Wang et al., 2014), which have only 4 cell types, E, B, F and R.

Studies with another genus of prawn, Farfantepenaeus brasiliensis and Penaeus semisulcatus also describe five types of cells in the hepatopancreas (Al-Mohanna and Nott, 1989; Vicentini et al., 2009; Nunes et al., 2014) which are also found in $M$. rosenbergii. They are: $\mathrm{E}$ cells (undifferentiated), F cells (fibrillar), B cells (vesicular), R cells (reabsorption), and $\mathrm{M}$ cells (basal). However, these studies do not describe the morphology of these tubules or the morphometry of the cells within the hepatopancreatic tubules.

The three regions, proximal, middle and distal, observed in the hepatopancreatic tubule, as described by Al-Mohanna and Nott (1987), are related to the cell differentiation model found in the hepatopancreas and the position of the cells along the tubules. Several models of cell differentiation have been described for decapods; however, the most accepted is the one developed by Hirsch and Jacobs (1930), in which the author 
emphasizes that the $\mathrm{R}$ and $\mathrm{F}$ cells are derived from the E cell, and the B cell from the F cell.

The E cells were observed only in the distal region of the tubules, corroborating the results found by Ribeiro et al. (2014) in the $M$. amozonicum species. This position is related to its function as an embryonic cell responsible for mitotic division with the objective of tubular epithelium renewal (Vicentini et al., 2009). Thus, it has the function of originating other tubular cells, and performing tubule growth, which occurs from the blind end, that is, from its distal portion to the proximal portion.

In our study, $\mathrm{M}$ cells were observed throughout the entire tubule. According to Vicentini et al. (2009), in studies with M. amozonicum, this type of cell progressively matures towards the proximal end of the hepatopancreatic tubule; however, we observed its proportion practically constant among the portions of the tubules. There areno morphometric studies of $\mathrm{M}$ cells in $F$. brasiliensis and F. brasiliensis; and A. astacus, $P$. agentinus and $L$. vannamei do not have this cell (Vogt et al., 1989; Sousa and Petriella, 2000; Wang et al., 2014). The intense basophilia observed in the cytoplasm of the $\mathrm{M}$ cell is due to the storage of nutrients. The study of AlMohanna and Nott (1989) also describes this basophilia in the M cell of Penaeus semisulcatus, corroborating these hypotheses. These authors also describe that the $\mathrm{M}$ cell has the function of storing nutrients, mainly because of its dense cellular material that is rich in proteins. The authors also point out that the differentiated position of this cell in relation to the other types occurs due to the fact that it has nutritional reserves, which are mobilized mainly during the moulting cycle. The accumulation of nutrients by this cell probably occurs by vessels that run under the epithelium, since its apex does not reach the lumen of the epithelium, thus the cell cannot absorb nutrients from the digestion that occurs in the lumen of the tubules. According to Brunet et al. (1994), during the prawn feeding period, the number of $M$ cells increases, and when the animals stop feeding, before and after molting, this material is used for cell maintenance. However, more morphometric studies involving the different moments of the moulting cycle of the species are necessary to fully elucidate the $\mathrm{M}$ cell function.
The M cell, unlike basal cells of other pseudostratified epithelium such as the trachea and uterine tube of animals such as cows and sows, does not act in the replacement of the different cells of the epithelium to which it belongs. In these epithelia they are also called germ cells, due to their function (Junqueira and Carneiro, 1983). Of the cells characterized in the hepatopancreas of $M$. rosenbergii, only the $\mathrm{M}$ cell did not show microvilli, which are structures that increase the area of contact with the content that passes through the lumen increasing the absorption, similar to what occurs with intestinal enterocytes, cells responsible for the absorption of nutrients. Therefore, it can be verified that the other cells (E, B, F and R) perform some type of absorption. Corroborating our study, literature also describes microvilli in hepatopancreas cells in M. amazonicum (Ribeiro et al., 2014; Marquez Junior, 2007; Nunes et al., 2014) and other species such as Neocaridina heterapoda (Sonakowska et al., 2016), F. brasiliensis (AlMohanna et al., 1987), and Penaeus semisulcatus (Al-Mohanna et al., 1989).

F cells showed cytoplasm with intense basophilia. This result corroborates the findings in M. amozonicum (Vicentini et al., 2009). This cell has a high rate of protein synthesis, and is responsible for the production of digestive enzymes (Vicentini et al., 2009), performing a function similar to that of the exocrine pancreas in this species. Corroborating this, a study with Astacus leptodactylus reports that the cytoplasm with intense basophilia observed in F cells is mainly linked to high RNA content (Souza and Petriella, 2000), which really must be connected with the large number of ribosomes responsible for the production of digestive enzymes.

According to Al-Mohanna; Nott (1989) when studying $P$. semissulcatus, at the end of the secretory process of enzymes performed by $\mathrm{F}$ cells, differentiation occurs in $\mathrm{B}$ cells. This phenomenon is characterized by the appearance of numerous small and dense pinocytic vacuoles. This cell differentiation corresponds to the end of the secretory activity and the onset of luminal substance absorption (Brunet et al., 1994). The aforementioned authors believe that this same model of cell differentiation, of $\mathrm{F}$ in $\mathrm{B}$, is valid for the other species of decapods and must also apply to $M$. rosenbergii. The observation in the study that there are more B cells in the middle 
and proximal portions can prove these claims since the differentiation sequence would be $\mathrm{E}$ cells in F cells, and only then in B. Thus, the portion in which more $\mathrm{E}$ (distal) cells are found would be the area with the least B cells.

B cells were the most observed in the hepatopancreatic tubules, mainly in the proximal and middle regions of the tubule. According to Ribeiro et al. (2014), B cells are responsible for intracellular digestion, and the absorbed material is accumulated in the large cytoplasmic vacuoles. In studies with $P$. semisulcatus, it is described that the pinocytic vacuoles in the apical region of the B-cell cytoplasm store nutrients absorbed from the hepatopancreatic lumen (Al-Mohanna and Nott, 1989). This is to be expected since there is the presence of apical microvilli, which have exactly the function of absorption. Apparently, the product of this intracellular digestion is exocytosed and added to the product of extracellular digestion in the lumen of the hepatopancreatic tubule through paracrine release by the F cell (Al-Mohanna and Nott, 1987) to nourish the animal. Some authors have suggested that the release of B cell content would occur in a holocrine (cell disruption) rather than a merocrine form. This would not be justified cytologically, since B cells have cytoplasmic vesicles of different sizes suggesting exocytosis, and not vesicles of the same size as in sebaceous glands, which have holocrine cells.

Then the assimilation of these nutrients occurs by another cell type, the R cells. These correlated functions of $B$ and $R$ cells may justify their higher numbers in the proximal portion of the tubules when compared to the distal portion, since it is in the proximal region in which there is a greater quantity of material ingested by the animals, which would justify a larger proportion of cells with intracellular digestion (B) and absorption (R).

The R cells were observed throughout the tubule, however, as already mentioned, their greatest concentration was in the proximal region, gradually decreasing to the distal region. According to studies by Wang et al. (2014), in Litopenaeus vannamei, the main function of $\mathrm{R}$ cells are the storage of nutrients, which can be in the form of lipid and/or glycogen droplets. This explains the coloration between basophil and acidophil, since lipid droplets are acidophilic and glycogen droplets are basophilic. Thus, R cells have absorptive and reserve functions, corroborating authors (Al-Mohanna and Nott, 1987). An apical surface with microvilli can be observed in these cells, which increases the area of contact with the food in the lumen and consequently the area of absorption, in addition to supranuclear vacuoles for nutrient storage. These characteristics corroborate the cell function of nutrient absorption, which can also be observed in the $\mathrm{R}$ cell of the species $P$. semisulcatus (Al-Mohanna and Nott, 1987). Vicentini et al. (2009), in studies with $M$. amozonicum, point out that reserves of glycogen and lipids stored in $\mathrm{R}$ cells can be mobilized to provide energy to the animal during the period of physiological abstinence that occurs at times of moulting and reproduction cycles, as occurs with the $\mathrm{M}$ cell. However, these authors point out that the function of this cell during the digestive cycle is not yet established for all decapods, although it seems to be the same for $M$. rosenbergii.

Histochemical staining technique showed a positive reaction to alcian blue in the lumen of the tubule for glycoproteins, in the case of mucin or mucus. This mucus must be secreted in the lumen of the tubules, protecting the tubule epithelium against mechanical aggression, pathogens and also against the digestion of the same enzymes produced by the hepatopancreas (cell F). This protection occurs in the same way in the gut of mammals and birds by goblet cells (França et al., 2015). In histological observations performed by Nunes et al. (2014) in the hepatopancreas of the $F$. brasiliensis species, the presence of neutral polysaccharides and acids in the lumen was also reported, attributing this characteristic to the release of material stored in the cells into the lumen of the tubules, but they do not mention which cell. Due to the histological characteristics presented by the $\mathrm{F}$ cells, as well as the cell positivity to PAS + alcian blue stain, the $F$ cell is responsible for the production and release of mucus (mucin), inside the lumen of the hepatopancreatic tubules, taking on a function analogous to the goblet cells of the intestines of the higher animals, besides producing digestive enzymes. 


\section{CONCLUSION}

M. rosenbergii has the hepatopancreas composed of blind tubules composed of a pseudo-stratified epithelium with 5 cell types (E, M, R, F and B) that appear in different proportions among the three portions of the tubules. In addition, we conclude that $\mathrm{F}$ cells, besides producing digestive enzymes, releasing mucin in the lumen of hepatopancreatic tubules.

\section{REFERENCES}

AL-MOHANNA, S.Y.; NOTT, J.A. Functional cytology of the hepatopancreas of Penaeus semisulcatus (Crustacea: Decapoda) during the moult cycle. Mar. Biol., v.101, p.535-544, 1989.

AL-MOHANNA, S.Y.; NOTT, J.A. R-cells and the digestive cycle in Penaeus semisulcatus (Crustacea: Decapoda). Mar. Biol., v.95, p.129137, 1987.

BARROS, H.P.; VALENTI, W.C. Comportamento alimentar do camarão de água doce, Macrobrachium rosenbergii (De Man) (Crustacea, Palaemonidae) durante a fase larval: análise qualitativa. Rev. Bras. Zool., v.10, p.785793, 1997.

BRUNET, M.; ARNAUD, J.; MAZZA, J. Gut structure and digestive cellular processes in marine Crustacea. Oceanogr. Mar. Biol. Ann. Rev. I, v.3, p.33-45, 1994.

DORMAN, H.P. The morphology and physiology of the hepatopancreas of Cambarus virilis. J. Morphol., v.45, p.505-535, 1928.

FRANÇA, A.M.; OLIVEIRA, C.B.; BEZERRA, H.O. et al. High incubation temperature and threonine dietary level improve ileum response against post-hatch salmonella enteritidis inoculation in broiler chicks. Plos One, v.10, p.113, 2015.

GIBSON, R.; BARKER, P.L. The decapod hepatopancreas. Oceanogr. Mar. Biol. Annu. Rev., v.17, p.285-346, 1979.

HIRSCH, G.C.; JACOBS, W. Der Arbeitsrhythmus der Mitteldarmdrüse von Astacus leptodactylus. J. Comp. Physiol. A. Neuroethol. Sens. Neural Behav. Physiol., v.12, p.524-558, 1930.
JACOBS, W. Untersuchungen über die Cytologie der Sekretbildung in der Mitteldarmdrüse von Astacus leptodactylus. Z. Zellforch. Microsk. Anat. Histochem., v.8, p.162,1928 .

MARQUES JUNIOR, J. Aspectos estruturas do hepatopâncreas do camarão de água doce Macrobrachium amazonicum (Heller, 1862). 2006. Dissertação (Mestrado em Aquicultura) Centro de Aquicultura, Universidade Estadual Paulista, Jaboticabal, SP.

NUNES, E.T.; BRAGA, A.A.; CAMARGOMATHIAS, M.I. Histochemical study of the hepatopancreas in adult females of the pinkshrimp Farfantepenaeus brasiliensis Latreille, 1817. Acta Histochem., v.116, p.243-251, 2014.

RIBEIRO, K.; PAPA, L.P.; VICENTINI, C.A.; FRANCESCHINI-VICENTINI, I.B. The ultrastructural evaluation of digestive cells in the hepatopancreas of the Amazon River prawn, Macrobrachium amazonicum. Aquacult. Res., v.47, p.1-9, 2014.

SOUSA, L.G.; PETRIELLA, A.M. Histology of the hepatopancreas of the freshwater prawn Palaemonetes argentinus (Crustacea, Caridea). Biocell, v.24, p.189-195, 2000.

VALENTI, W.C. A modernização da carcinicultura de água doce. Rev. Assoc. Bras. Criadores Camarões, v.3, p.56-58, 2001.

VICENTINI, I.B.F.; RIBEIRO, K.; PAPA, L.P. et al. Histoarchitectural features of the hepatopancreas of the Amazon river prawn Macrobrachium amazonicum. Int. J. Morphol., v.27, p.121-128, 2009.

VOGT, G.; STOCKER, W.; ZWILLING, R. Biosynthesis of Astacus proteases, a digestive enzyme from crayfish. Histochemistry, v.91, p.373-381, 1989.

WANG, X.; LI, C.; XU, C. et al. Growth, body composition, ammonia tolerance and hepatopancreas histology of white shrimp Litopenaeus vannamei fed diets containing diferente carbohydrate sources at low salinity. Aquac. Res., p.1-12, 2014. 